\title{
Civilisations
}

Revue internationale d'anthropologie et de sciences

humaines

$41 \mid 1993$

Mélanges Pierre Salmon II

\section{Biographie de Pierre Salmon}

\section{(2) OpenEdition}

Journals

Édition électronique

URL : http://journals.openedition.org/civilisations/1601

DOI : 10.4000/civilisations. 1601

ISSN : 2032-0442

\section{Éditeur}

Institut de sociologie de l'Université Libre de Bruxelles

\section{Édition imprimée}

Date de publication : 1 septembre 1993

Pagination : 13-18

ISBN : 2-87263-094-5

ISSN : 0009-8140

Référence électronique

«Biographie de Pierre Salmon », Civilisations [En ligne], 41 | 1993, mis en ligne le 30 juin 2009, consulté le 02 mai 2019. URL : http://journals.openedition.org/civilisations/1601 ; DOI : 10.4000/

civilisations. 1601

Ce document a été généré automatiquement le 2 mai 2019.

(c) Tous droits réservés 


\section{Biographie de Pierre Salmon}

\section{Version française}

1 Né à Liège le 30 novembre 1926, Pierre Salmon conduira ses études supérieures à l'U.L.B., où il sera successivement licencié en Philosophie et Lettres, groupe Histoire en juillet 1950, puis agrégé de l'enseignement moyen du degré supérieur en décembre de la même année et docteur en mai 1961. Lauréat des Bourses de Voyages en 1951, il séjournera à l'Academia Belgica de Rome et sera en 1953-54, pensionnaire de l'Ecole Normale Supérieure de Paris. C'est alors à l'histoire de l'Antiquité qu'il se consacre et il publie, en 1965, un ouvrage fondamental sur la Politique égyptienne d'Athènes au VI et $V^{e}$ siècles avant JC. Un livre écrit en collaboration avec Georges Nachtergael, Des Gracques à Auguste, vaut à ses deux auteurs d'être lauréats du Prix Joseph De Keyn en 1965.

Le travail de P. Salmon sur la politique égyptienne d'Athènes lui faisait déjà mettre un pied sur le continent africain, mais le passage essentiel s'opère le $1^{\text {er }}$ juillet 1959 quand il devient collaborateur scientifique au Centre scientifique et médical de l'U.L.B. en Afrique centrale, poste qu'il occupera jusqu'au 31 décembre 1967. Le $1^{\text {er }}$ janvier 1968, il devient Collaborateur au Centre d'Etudes Africaines de l'Institut de Sociologie de l'ULB, Centre dont il deviendra co-directeur le $1^{\mathrm{er}}$ octobre 1984 . Son intérêt principal se tourne vers l'histoire de l'Afrique, à laquelle il va consacrer de nombreux livres et articles, de $L a$ reconnaissance Graziani chez les Sultans du nord de l'Uélé, en 1963, jusqu'à La carrière africaine de Harry Bombeeck, agent commercial, en 1990, et surtout, en 1986, sa fondamentale Introduction à l'histoire de l'Afrique.

Parallèlement, il mène une carrière pédagogique à l'Athénée Léon Lepage (1950-1963), à l'Institut d'Enseignement supérieur Lucien Cooremans (1961-1978) puis surtout au Centre Universitaire de l'Etat à Anvers (depuis 1963) et à l'ULB (depuis 1970). Dans cette dernière institution, il développera, principalement à la Faculté des Sciences Sociales, Politiques et Economiques, des enseignements liés à ses deux orientations principales de recherche, enseignements concernant aussi bien «La Société et les Institutions de l'Antiquité » que «L'Ethnohistoire de l'Afrique ».

4 Mais ses préoccupations s'élargissent, un cours de "Critique historique" lui est confié, et il publie Histoire et Critique (1969), un ouvrage qui sera traduit en espagnol et en portugais. 
Ses soucis éthiques lui font écrire Le Racisme devant l'Histoire (1973) comme ses pratiques de loisir l'incitent à nous donner De la Collection au Musée (1958). Son activité d'écriture est débordante : il n'est pas possible de donner ici la liste de ses publications, marques d'une activité de recherche diverse, mais jamais relâchée, et qui vaut à son auteur l'estime de ses pairs.

Pierre Salmon est élu membre associé de l'Académie des Sciences d'Outre Mer à Paris, en 1973, puis, en 1977, membre de la classe des Sciences morales et politiques de l'académie Royale des Sciences d'Outre Mer. Il est également membre correspondant de l'Académie Européenne des Sciences des Arts et des Lettres depuis 1982.

Ses voyages et séjours à l'étranger sont nombreux, et là non plus il n'est pas possible de dresser un inventaire. On peut le rencontrer aussi bien en Europe (il sera " professore a contratto » à l'Université de Milan) qu'à Téhéran et Jérusalem, et surtout bien sûr en Afrique, Professeur visiteur à Lubumbashi, Bujumbura, Yaounde, Abidjan, Niamey, Cotonou et Kisangani. "Vous êtes sans doute l'un des historiens, sinon l'historien de notre Université le plus connu à l'étranger » lui dira $\mathrm{M}^{\mathrm{me}}$ le Recteur Thys-Clément lors de la séance d'hommage aux Professeurs honoraires, le 20 novembre 1992.

7 C'est en effet à la fin de l'année académique 1991-1992 que Pierre Salmon, admis à l'honorariat, abandonne l'essentiel de ses fonctions dans une Université à laquelle il a beaucoup donné et donnera encore, une Université à la gestion de laquelle il a été associé, comme Membre du Conseil d'administration (1976-1978 et 1986-1988), Président de la Section des Sciences sociales (1976-1978), Conseiller du Recteur pour les problèmes de coopération (1989-1992), puis Secrétaire général du Conseil de la Coopération (1991) et ce ne sont là que quelques unes des fonctions assumées.

Partout, toujours, il fera la preuve aussi bien de sa capacité de travail, de son sens de l'efficacité, que de son ouverture d'esprit, de son affabilité, d'une gentillesse qui l'ont fait apprécier de ses étudiants, de ses collègues, autant que des nombreux interlocuteurs qu'il a pu rencontrer lors de ses voyages à travers le monde.

9 L'abondance et la qualité des contributions réunies dans ces deux tomes d'hommages en sont la preuve. Tous les coauteurs émettent le voeu de voir Pierre Salmon continuer à produire longtemps, avec constance, de ces travaux qui nous sont si précieux.

\section{English version}

Born in Liège on $30^{\text {th }}$ November 1926 , Pierre Salmon graduated with a degree in 'Philosophie et Lettres', specialising in history, from the Université Libre de Bruxelles in July 1950, obtained his teaching diploma for secondary schools and then obtained his doctorate in May 1961. As the successful winner of a travel scholarship in 1951, he stayed at the Academia Belgica in Rome and then spent 1953-54 as an intern at the Ecole Normale Supérieure in Paris. He specialised in Ancient History and published, in 1965, a key text on Athens' Egyptian policy in the $\mathrm{VI}^{\text {th }}$ and $\mathrm{V}^{\text {th }}$ centuries B.C. The book, which he wrote in collaboration with Georges Nachtergael, "Des Gracques à Auguste" earned its authors the Joseph de Keyn Prize in 1965.

11 Pierre Salmon's work on the Athens' Egyptian policy had already directed his interest to the African continent, but the main thrust of his African work started on $1^{\text {st }}$ July 1959 when he became a scientific associate at the Scientific and Medical Centre of the U.L.B., in Central Africa, a post which he held until $31^{\text {st }}$ December 1967. On $1^{\text {st }}$ January 1968 , he 
moved to the Centre of African Studies at the Institute of Sociology at the U.L.B., becoming co-director of the Centre on $1^{\text {st }}$ October 1984. African history became his main interest and he wrote numerous books and articles on the subject from "La reconnaissance Graziani chez les Sultans du nord de l'Uélé", in 1963, to "La carrière Africaine de Harry bombeeck, agent commercial", in 1990, and above all, in 1986, one of his key works "Introduction à l'histoire de l'Afrique".

At the same time, he carried on his teaching career at the Léon Lepage Atheneum (1950-1963), at the Lucien Cooremans Institute for Higher Education (1961-1978), and particularly at the State University in Antwerp (from 1963) and at the U.L.B. (from 1970). It was at the U.L.B. that the principally developed in the Faculty of Social Science, Politics and Economics, courses linked to his two main fields of research such as "La société et les Institutions de l'Antiquité" and "l'Ethnohistoire de l'Afrique".

However, his interest began to widen and he was entrusted with the task of preparing a course on historical criticism which led to the "Histoire et Critique" published in 1969 and later translated into Spanish and Portuguese. His ethical concerns moved him to write "Le racisme devant l'Histoire" (1973) and his leisure activities led him to produce "De la Collection au Musée" (1958). His writings proliferated and it is impossible to list here all his publications, characterised by his thorough research which earned him considerable esteem from his peers.

Pierre Salmon was elected associate member of the Académie des Sciences d'Outre-Mer in Paris in 1973, then, in 1977, member of the classe des Sciences morales et politiques de l'Académie Royale des Sciences d'Outre-Mer. He has also been a 'membre correspondant' de l'Académie Européenne des Sciences des Arts et des Lettres since 1982.

He has widely travelled and once again it is not possible to provide a list here. He was to be seen in Europe (he was 'Professore a contratto' at the University of Milan) as well as Teheran and Jerusalem, and naturally enough in Africa where he was Visiting Professor at Lubumbashi, Bujumbura, Yaounde, Abidjan, Niamey, Cotonou and Kisingani. "You are without doubt one of the historians, if not the historian, from our university who is the best known abroad", commented $\mathrm{M}^{\text {rs }}$ Thys-Clément, Vice-Chancellor of the U.L.B., while paying tribute to a group of emeritus professors at the university, on $20^{\text {th }}$ November 1992.

The end of the academic year 1991-1992 saw Pierre Salmon relinquish most of his functions at the university to which he had contributed so much and will continue to contribute not only in academic terms but also in its administration. He was a member of the university's governing body (1976-1978 and 1986-1988), President of the department of Social Sciences (1976-1978), Advisor to the Vice-Chancellor on matters of co-operation (1989-1992), then Secretary-General of the Co-operation Council (1991), to name but a few of the offices he has held.

Wherever and whenever he has shown his capacity for work, his efficiency, his open mind, and his affability and kindness, all of which have earned him the esteem of his students, colleagues and the numerous people with whom he has come into contact in his travels throughout the world.

Both the quantity and the quality of the contributions brought together in these two volumes dedicated to him serve as a token of this esteem. All the authors published in these volumes join in the wish to see Pierre Salmon continue his valuable work for a long time to come. 